\title{
A Selective Fluorescent Sensor for Detecting Lead in Living Cells
}

\author{
Qiwen He, Evan W. Miller, Audrey P. Wong, and Christopher J. Chang* \\ Department of Chemistry, University of California, Berkeley, CA 94720
}

Synthetic Materials and Methods. Silica gel P60 (SiliCycle) was used for column chromatography. Analytical thin layer chromatography was performed using SiliCycle 60 F254 silica gel (precoated sheets, $0.25 \mathrm{~mm}$ thick). 2-Anilinoethanol, 2-(2-chloroethoxy)ethanol, potassium tert-butoxide, phosphorus oxychloride, and 2,3-dichloro-5,6-dicyano-1,4benzoquinone (DDQ) were purchased from Acros Organics (Morris Plains, NJ) and were used as received. Methanesulfonic acid was purchased from Alfa Aesar (Ward Hill, MA) and was used as received. Resorcinol was purchased from MC\&B and was used as received. All other chemicals were purchased from Sigma-Aldrich (St. Louis, MO) and were used as received. ${ }^{1} \mathrm{H}$ NMR spectra were collected in $\mathrm{CDCl}_{3}$ or $\mathrm{CD}_{3} \mathrm{OD}$ (Cambridge Isotope Laboratories, Cambridge, MA) at $25{ }^{\circ} \mathrm{C}$ on a Bruker AV-300 or AV-400 spectrometer at the College of Chemistry NMR Facility at the University of California, Berkeley. All chemical shifts are reported in the standard $\delta$ notation of parts per million using the peak of residual proton signals of $\mathrm{CDCl}_{3}$ or $\mathrm{CD}_{3} \mathrm{OD}$ as an internal reference. Low- and high-resolution mass spectral analyses were carried out at the College of Chemistry Mass Spectrometry Facility at the University of California, Berkeley.

2-\{[2-(2-Hydroxyethoxy)ethyl]phenylamino\}ethanol (1). A suspension of 2-anilinoethanol (0.69 g, $0.63 \mathrm{~mL}, 5.0 \mathrm{mmol})$, 2-(2-chloroethoxy)ethanol $(1.02 \mathrm{~g}, 0.87 \mathrm{~mL}, 8.2 \mathrm{mmol})$, and calcium carbonate $(0.35 \mathrm{~g}, 3.5 \mathrm{mmol})$ in $20 \mathrm{~mL}$ of water was refluxed overnight with vigorous stirring under a nitrogen atmosphere. The reaction was filtered, and the filtrate was extracted three times with dichloromethane. The organic phases were combined, dried over $\mathrm{Na}_{2} \mathrm{SO}_{4}$, and the solvent was removed by rotary evaporation. Purification by flash column chromatography (silica gel, 1:1 toluene/acetonitrile) provided pure 1 as a colorless oil $\left(0.75 \mathrm{~g}, 66 \%\right.$ yield). ${ }^{1} \mathrm{H}$ NMR $\left(\mathrm{CDCl}_{3}, 300 \mathrm{MHz}\right): \delta 7.31-7.15(2 \mathrm{H}, \mathrm{m}), 6.80-6.65(3 \mathrm{H}, \mathrm{m}), 4.06(1 \mathrm{H}, \mathrm{t}, J=6.0 \mathrm{~Hz}), 3.86-$ 3.76 $(2 \mathrm{H}, \mathrm{m}), 3.75-3.69(4 \mathrm{H}, \mathrm{m}), 3.68-3.60(2 \mathrm{H}, \mathrm{m}), 3.59-3.51(4 \mathrm{H}, \mathrm{m}), 3.15-3.05(1 \mathrm{H}, \mathrm{m})$. FABMS: calculated for $\left[\mathrm{MH}^{+}\right]: 226$, found 226 .

(2-\{[2-(2-Ethoxycarbonylmethoxyethoxy)ethyl]phenylamino\}ethoxy)acetic acid ethyl ester (2). Under a nitrogen atmosphere, potassium tert-butoxide $(2.6 \mathrm{~g}, 23.2 \mathrm{mmol})$ was added to a solution of diol $1(1.0 \mathrm{~g}, 4.6 \mathrm{mmol})$ in $20 \mathrm{~mL}$ of tert-butanol and the mixture was refluxed for 2 h. Next, a solution of bromoacetic acid $(1.3 \mathrm{~g}, 9.4 \mathrm{mmol})$ in $10 \mathrm{~mL}$ of tert-butanol was added dropwise into the reaction. The resulting suspension was refluxed overnight under nitrogen, cooled to room temperature, quenched with $1 \mathrm{M} \mathrm{HCl}(36 \mathrm{~mL})$, and the solvents were removed under reduced pressure. The remaining residue was treated with absolute ethanol to precipitate a white solid and filtered. The filtrate was collected, combined with $35 \mathrm{~mL}$ benzene, and refluxed for $24 \mathrm{~h}$. The solvents were removed by rotary evaporation, and purification by flash column chromatography (silica gel, 3:1 toluene/acetonitrile) afforded 2 as a yellow oil (1.1 g, 61\% yield). ${ }^{1} \mathrm{H}$ NMR $\left(\mathrm{CDCl}_{3}, 300 \mathrm{MHz}\right): \delta$ 7.28-7.15 $(2 \mathrm{H}, \mathrm{m}), 6.80-6.65(3 \mathrm{H}, \mathrm{m}), 4.31-4.21(6 \mathrm{H}, \mathrm{m}), 4.17$ $(2 \mathrm{H}, \mathrm{s}), 4.11(2 \mathrm{H}, \mathrm{s}), 3.78-3.60(12 \mathrm{H}, \mathrm{m}), 1.40-1.28(6 \mathrm{H}, \mathrm{m})$. FAB-MS: calculated for $\left[\mathrm{MH}^{+}\right]$: 398 , found 398 . 
\{2-[[2-(2-Ethoxycarbonylmethoxyethoxy)ethyl]-(4-formylphenyl)amino]ethoxy\}acetic acid ethyl ester (3). Under a nitrogen atmosphere, a solution of $2(2.0 \mathrm{~g}, 5.0 \mathrm{mmol})$ in $20 \mathrm{~mL}$ of dry 1,2-dichloroethane was added dropwise into a mixture of dry DMF $(4.9 \mathrm{~mL}, 60 \mathrm{mmol})$ and $\mathrm{POCl}_{3}(3.76 \mathrm{~mL}, 40 \mathrm{mmol})$ in $30 \mathrm{~mL}$ of 1,2-dichloroethane. The reaction was refluxed overnight under nitrogen, cooled to room temperature, and poured into an aqueous solution containing 7.8 $\mathrm{g}$ of sodium acetate. The mixture was extracted three times with dichloromethane, and the organic phases were separated, dried over $\mathrm{Na}_{2} \mathrm{SO}_{4}$, and the solvent was removed by rotary evaporation. Purification by flash column chromatography (silica gel, $10 \%$ methanol/dichloromethane) furnished 3 as a yellow oil (1.1 g, 50\% yield). ${ }^{1} \mathrm{H}$ NMR $\left(\mathrm{CDCl}_{3}, 300\right.$ MHz): $\delta 9.69(1 \mathrm{H}, \mathrm{s}), 7.67(2 \mathrm{H}, \mathrm{d}, J=9.0 \mathrm{~Hz}), 6.73(2 \mathrm{H}, \mathrm{d}, J=9.0 \mathrm{~Hz}), 4.24-4.11(4 \mathrm{H}, \mathrm{m}), 4.08$ $(2 \mathrm{H}, \mathrm{s}), 4.05(2 \mathrm{H}, \mathrm{s}), 3.71-3.60(12 \mathrm{H}, \mathrm{m}), 1.31-1.18(6 \mathrm{H}, \mathrm{m})$. FAB-MS: calculated for $\left[\mathrm{MH}^{+}\right]$: 426 , found 426 .

(2-\{\{4-Bis-(2,4-dihydroxyphenyl)methyl\}phenyl\}-[2-(2-ethoxycarbonylmethoxyethoxy)ethyl]amino)ethoxyethoxy)ethyl]amino\}ethoxy)acetic acid ethyl ester (4). The synthesis of 4 employed a methodology recently reported for the two-step synthesis of xanthenones. ${ }^{1}$ To an oven-dried flask was added resorcinol $(0.55 \mathrm{~g}, 5.0 \mathrm{mmol})$ and aldehyde $3(1.1 \mathrm{~g}, 2.5 \mathrm{mmol})$. The solids were dissolved in a 1:1 mixture of dichloromethane and ether $(10 \mathrm{~mL}$ each). Then, $\mathrm{MeSO}_{3} \mathrm{H}(1.8 \mathrm{~mL}, 8 \% \mathrm{v} / \mathrm{v})$ was added and the resulting pink mixture was stirred for $2 \mathrm{~h}$ at room temperature. The reaction was diluted with ethyl acetate and poured into an aqueous solution containing $2.2 \mathrm{~g}$ of sodium bicarbonate. The $\mathrm{pH}$ of the aqueous layer was adjusted to $\mathrm{pH} 4-5$ by the addition of conc $\mathrm{HCl}$ and then extracted with ethyl acetate. The organic layers were combined, washed with water, dried over $\mathrm{Na}_{2} \mathrm{SO}_{4}$, and the solvent was removed by rotary evaporation. Purification by flash column chromatography (silica gel, $1: 1$ toluene/acetone $+1 \%$ acetic acid) delivered 4 as a pale red oil $(0.22 \mathrm{~g}, 14 \%$ yield $) .{ }^{1} \mathrm{H} \mathrm{NMR}\left(\mathrm{CDCl}_{3}, 300 \mathrm{MHz}\right): \delta 6.83$ $(2 \mathrm{H}, \mathrm{d}, J=8.7 \mathrm{~Hz}), 6.61(2 \mathrm{H}, \mathrm{d}, J=8.7 \mathrm{~Hz}), 6.52(2 \mathrm{H}, \mathrm{d}, J=8.4 \mathrm{~Hz}), 6.24(2 \mathrm{H}, \mathrm{d}, J=8.1 \mathrm{~Hz})$, $6.14\left(2 \mathrm{H}, \mathrm{dd}, J_{1}=8.1 \mathrm{~Hz}, J_{2}=2.4 \mathrm{~Hz}\right), 5.77(1 \mathrm{H}, \mathrm{s}), 4.20-4.05(8 \mathrm{H}, \mathrm{m}), 3.70-3.48(12 \mathrm{H}, \mathrm{m}), 1.22$ $(3 \mathrm{H}, \mathrm{t}, J=7.2 \mathrm{~Hz}), 1.21(3 \mathrm{H}, \mathrm{t}, J=7.2 \mathrm{~Hz})$. FAB-MS: calculated for $\left[\mathrm{MH}^{+}\right]$: 628 , found 628 .

\section{(2-\{[2-(2-Ethoxycarbonylmethoxyethoxyethoxy)ethyl]-[4-(6-hydroxy-3-oxo-3H-xanthen-9-} yl)phenyl]amino\}ethoxy)acetic acid ethyl ester (Leadfluor-1 Ethyl Ester, 5). A solution of 2,3-dichloro-5,6-dicyano-1,4-benzoquinone (DDQ, $159 \mathrm{mg}, 0.70 \mathrm{mmol}$ ) in 1:1 AcOH/benzene $(10 \mathrm{~mL})$ was added dropwise into a solution of triarylmethane $5(219 \mathrm{mg}, 0.35 \mathrm{mmol})$ in $10 \mathrm{~mL}$ of 1:1 AcOH/benzene at room temperature. The resulting purple-colored mixture was stirred overnight at room temperature. The reaction was concentrated in vacuo, and purification by preparative thin-layer chromatography (silica gel, 4.5:4.5:1 dichloromethane/ethyl acetate/methanol) gave pure 5 as a dark orange solid ( $87 \mathrm{mg}, 41 \%$ yield). ${ }^{1} \mathrm{H}$ NMR $\left(\mathrm{CD}_{3} \mathrm{OD}, 400\right.$ MHz): $\delta 7.40(2 \mathrm{H}, \mathrm{d}, J=9.2 \mathrm{~Hz}), 7.26(2 \mathrm{H}, \mathrm{d}, J=8.8 \mathrm{~Hz}), 6.98(2 \mathrm{H}, \mathrm{d}, J=8.8 \mathrm{~Hz}), 6.63(2 \mathrm{H}, \mathrm{d}$, $J=9.2 \mathrm{~Hz}), 6.56(2 \mathrm{H}, \mathrm{s}), 4.24-4.11(8 \mathrm{H}, \mathrm{m}), 3.80-3.64(12 \mathrm{H}, \mathrm{m}), 1.24(3 \mathrm{H}, \mathrm{t}, J=7.2 \mathrm{~Hz}), 1.22$ $(3 \mathrm{H}, \mathrm{t}, J=7.2 \mathrm{~Hz})$. HRFAB-MS: calculated for $\left[\mathrm{MH}^{+}\right] \mathrm{C}_{33} \mathrm{H}_{38} \mathrm{NO}_{10}$ : 608.2496, found 608.2499.

Leadfluor-1 (LF1, 6). Solutions of diester 5 were saponified under basic conditions to generate free LF1 using a standard protocol. $^{2}$ In a typical preparation, a solution of 5 in a 1:1 tetrahydrofuran/methanol mixture under a nitrogen atmosphere was cooled to $0{ }^{\circ} \mathrm{C}$ and treated with 15 equiv of lithium hydroxide. The resulting mixture was stirred for 2 days under nitrogen, at which time TLC analysis showed complete consumption of starting material. The reaction was 
evaporated to dryness and the remaining residue was directly used to prepare stock solutions in

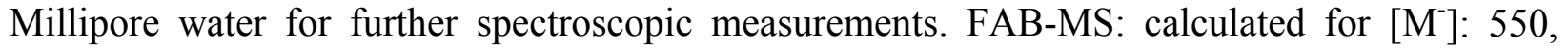
found 550. The membrane-permeable, tri-acetoxymethyl ester of LF1 (LF1-AM) was prepared directly from LF1 by reaction with acetoxymethyl bromide and triethylamine in DMF solution. FAB-MS: calculated for $\left[\mathrm{MH}^{+}\right]$: 768, found 768 .

Spectroscopic Materials and Methods. Millipore water was used to prepare all aqueous solutions. All spectroscopic measurements were performed in $20 \mathrm{mM}$ HEPES buffer, pH 7. Absorption spectra were recorded on a Varian Cary 50 spectrophotometer (Walnut Creek, CA) and fluorescence spectra were recorded using a Photon Technology International Quanta Master 4 L-format scanning spectrofluorometer (Lawrenceville, NJ) equipped with an LPS-220B 75-W xenon lamp and power supply, A-1010B lamp housing with integrated igniter, switchable 814 photon-counting/analog photomultiplier detection unit, and MD5020 motor driver. Samples for absorption and emission measurements were contained in $1-\mathrm{cm} \times 1-\mathrm{cm}$ quartz cuvettes $(1.4$ or 3.5-mL volume, Starna, Atascadero, CA). Fluorescence quantum yields were determined by reference to fluorescein in $0.1 \mathrm{~N} \mathrm{NaOH}(\Phi=0.95) .{ }^{3}$ The binding affinity of $\mathrm{Pb}^{2+}$ to $\mathrm{LF} 1$ was measured in $20 \mathrm{mM}$ HEPES, $\mathrm{pH}$ 7. Excitation was provided at $490 \mathrm{~nm}$, and collected emission was integrated from 500 to $700 \mathrm{~nm}$. The apparent dissociation constant $\left(K_{\mathrm{d}}\right)$ was determined using the following equation: $\mathrm{F}=\left(\mathrm{F}_{\max }\left[\mathrm{Pb}^{2+}\right]+\mathrm{F}_{\min } K_{\mathrm{d}}\right) /\left(K_{\mathrm{d}}+\left[\mathrm{Pb}^{2+}\right]\right)$, where $\mathrm{F}$ is the observed fluorescence, $\mathrm{F}_{\max }$ is the fluorescence for the $\mathrm{Pb}^{2+}: \mathrm{LF} 1$ complex, and $\mathrm{F}_{\min }$ is the fluorescence for the free LF1 dye.

Preparation and Staining of Cell Cultures. Cells were grown in the Tissue Culture Facility at the University of California, Berkeley with expert technical assistance from Ann Fischer and Stephanie Bumbaca. HEK 293T cells were cultured in Dulbecco's Modified Eagle Medium (DMEM, Invitrogen, Carlsbad, CA) supplemented with 10\% Fetal Bovine Serum (FBS, Invitrogen) and glutamine $(2 \mathrm{mM})$. One day before imaging, cells were passed and plated on 18$\mathrm{mm}$ glass coverslips coated with poly-L-lysine $(50 \mu \mathrm{g} / \mathrm{mL}$, Sigma, St. Louis, MO). Immediately before the experiments, cells were washed with DMEM, incubated with the probe in DMEM, washed with PBS, and imaged. Experiments to assess lead uptake were performed in the same media supplemented with $200 \mu \mathrm{M} \mathrm{Pb}(\mathrm{OAc})_{2}$ and $1 \mathrm{mM}$ sodium citrate.

Fluorescence Imaging Experiments. Confocal fluorescence images were acquired at Molecular Imaging Center at the University of California, Berkeley. Imaging experiments were performed with a Zeiss LSM510 META/NLO Axioplan 2 laser scanning microscope and a 40x waterimmersion objective lens. Excitation of LF1-loaded cells at $488 \mathrm{~nm}$ was carried out with an argon ion laser, and emission was collected in a window from $494 \mathrm{~nm}$ to $558 \mathrm{~nm}$ using a META detection system. LF1-AM $(20 \mu \mathrm{M})$ was incubated with live cell samples for $15-90 \mathrm{~min}$ at $37^{\circ} \mathrm{C}$. Additions of TPEN were performed directly on the microscope stage.

1. Bacci, J. P.; Kearney, A. M.; Van Vranken, D. L. J. Org. Chem. 2005, 70, 9051-9053.

2. Basarić, N.; Baruah, M.; Qin, W.; Metten, B.; Smet, M.; Dehaen, W.; Boens, N. Org. Biomol. Chem. 2005, 3, 2755-2761.

3. Brannon, J. H.; Magde, D. J. Phys. Chem. 1978, 82, 705-709. 

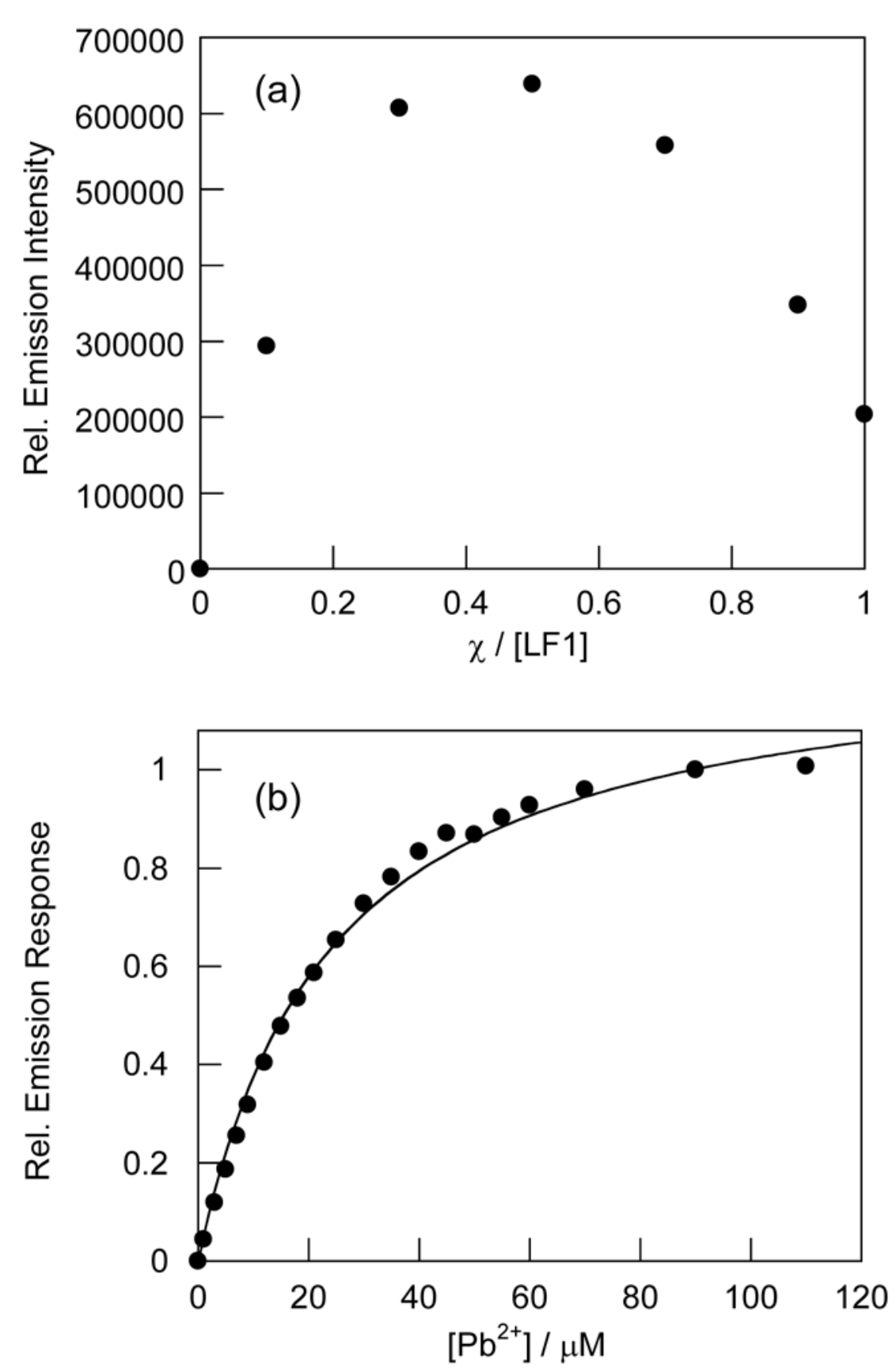

Figure S1. (a) Job's plot of LF1 and $\mathrm{Pb}^{2+}$. The total concentration of LF1 and $\mathrm{Pb}^{2+}$ were kept at a constant $10 \mu \mathrm{M}$. Excitation was provided at $490 \mathrm{~nm}$ and emission intensity was measured at 514 $\mathrm{nm}$. Spectra were acquired in $20 \mathrm{mM}$ HEPES, $\mathrm{pH}$ 7. The data are consistent with a $1: 1 \mathrm{~Pb}^{2+}: \mathrm{LF} 1$ complex. (b) Normalized fluorescence responses of $10 \mu \mathrm{M} L F 1$ to $\mathrm{Pb}^{2+}$ solutions for $K_{\mathrm{d}}$ value determination. Excitation was provided at $490 \mathrm{~nm}$ and the collected emission was integrated from 500 to $700 \mathrm{~nm}$. Spectra were acquired in $20 \mathrm{mM}$ HEPES, $\mathrm{pH}$ 7. The points shown are for $\mathrm{Pb}^{2+}$ added at $0,1,3,5,7,9,12,15,18,21,25,30,35,40,45,50,55,60,70,90$, and $110 \mu \mathrm{M}$, respectively. The observed $K_{\mathrm{d}}$ value is $23 \pm 4 \mu \mathrm{M}$. 